\title{
A Review on Scenario of Agriculture in India and Punjab 1900-2019
}

\author{
Jaihoon Rafie and Raj Kumar* \\ Department of Soil Science, School of Agriculture, \\ Lovely Professional University, Phagwara, Punjab, India \\ *Corresponding author
}

\section{A B S T R A C T}

\begin{tabular}{|l|}
\hline Ke y w or d s \\
Indian economy, \\
$\begin{array}{l}\text { Food productivity, } \\
\text { Land markets }\end{array}$ \\
\hline Article Info \\
\hline $\begin{array}{l}\text { Accepted: } \\
\text { 30 May 2020 } \\
\text { Available Online: } \\
\text { 10 June 2020 }\end{array}$ \\
\hline
\end{tabular}

Agriculture is the backbone of the Indian economy. The geographical position of India has been very friendly for agricultural activities. The physical factors existing in India such as climate, soil, and relief became very helpful in the cultivation of so many crops. So from long past, the Indians had taken agriculture as their basic means of livelihood. In the coming years it will be essential to increase food productivity in developing countries especially India. This however requires finding viable solutions to a number of complex technical, institutional and policy issues including land markets, research on seeds and inputs: agricultural extension; credit; rural infrastructure; storage connection to markets; rural nonfarm employment and food price stabilization. This paper reviews the state of agriculture in the past 100 years in India and state of Punjab. Moreover it discussed the development of agriculture from early 1900 to 2019 and the role played by agriculture in the development process and the interactions between agriculture and other economic sectors; the determinants of the Green revolution and discuss the foundations of agriculture growth in India and Punjab; the rural development along with the effect of green revolution in the economic development of the country.

\section{Introduction}

Agriculture is the backbone of the Indian economy. The geographical position of India has been very friendly for agricultural activities. The physical factors existing in India such as climate, soil, and relief became very helpful in the cultivation of so many crops. So from long past, the Indians had taken agriculture as their basic means of livelihood (Qadri, 2018). Over a period of 190 years, there was hardly any change in the form of technology in India from 1757 to
1947. For most of the farmers, agriculture was a means of existence, nearly 70 per cent of the total population derived their livelihood from agriculture itself. The villagers were selfsufficient to barter their products with each other, grain was the standard value.

There was a natural economy and the money economy was rear. There was a rapid change in the structure of the rural economy when money entered the market through the process of commercialization of agriculture in the middle of the $19^{\text {th }}$ century. 
The commercialization of agriculture was more pronounced when the British become the major ruling power in India (Gadgil, 1933). However, since the beginning of $19^{\text {th }}$ century, agriculture did not contribute significantly in the economic growth of India. Before the initiation of the planning era in 1951, the progress of India's agriculture was quite deplorable. For the long period of 47 years from 1900 to 1947, the trend growth rate in the agriculture sector had stagnated at about 0.2 per annum while, from 1950-51 to 1985-86 India agriculture had grown annually at a compound rate of 2.66 per cent (Joshi et al., 2006).

Then from mid-1960 onwards the traditional agriculture practices were continuously replaced by modern technology and farm practices in India. The Green Revolution started in India during the 1960s to elevated the food production and feed the millions of people across the country. It was also credited with increase in agricultural yields in many places where the technology was accepted (Sebby, 2010).

The Green Revolution started with the aid of the Rockefeller Foundation- a United Statesbased organisation and was centred on highyielding varieties of wheat, rice, and other grains which were developed in Mexico and in the Philippines. In the early years of 1960 the area under the high yielding varieties program was only 1.9 million hectares which increased to nearly 15.4 million hectares, 43.1 million hectares and 63.9 million hectares in the first years of 1970, 1980 and 1990 respectively.

Between 1965 and the early 1980s, northern and north-western states of India experienced the most benefits of this revolution. The program led to a significant increase in the production of food grains, mainly wheat and rice. High yielding varieties of wheat were sown about 75 per cent of the total cropped area in 1980s (Heitzman and Worden, 1995).

Growth in agricultural GDP showed high instability since the beginning of economic reforms in 1991. It varied from 4.8 per cent per annum in 1992-96 to a low of 2.4 per cent during 2002-06 before rising to 4.1 per cent in 2007-12. In 2013-14, the area and production under wheat increased to 30.47 million hectares and 95.85 million tonnes in comparison to 27.99 million hectares and 75.81 million tonnes in 2006-07 (Government of India, 2016).

Area, production, and yield of major crops in India are shown in figure 1, 2, and 3 respectively. In 1950-51 wheat covered 9.75 million hectares which increased to 330.42 million hectares in 2015-16, rice increased from 30.81 million hectares in 1950-51 to 43.50 million hectares in 2015-16. The area under maize and pulses in 1950-51 were 3.16 and 19.9 million hectares in India which were increased to 8.81 and 24.91 million hectares in 2015-16 respectively. The production of wheat and rice was 6.46 and 20.58 million tons which increased to 92.22 and 104.41 million ton respectively, while the yield of wheat in 1950-51 was $663 \mathrm{~kg} / \mathrm{ha}$ and it's increased to $3034 \mathrm{~kg} / \mathrm{ha}$ in $2015-16$. The yield of rice increased from 668 in $1950-51 \mathrm{~kg} / \mathrm{ha}$ to $2400 \mathrm{~kg} / \mathrm{ha}$ in $2015-16$. The yield of maize increased from $547 \mathrm{~kg} / \mathrm{ha}$ in $1950-51$ to 2563 $\mathrm{kg} / \mathrm{ha}$ in 2015-16. The yield of pulses increased from $441 \mathrm{~kg} / \mathrm{ha}$ in $1950-51$ to 789 $\mathrm{kg} / \mathrm{ha}$ in 2012-13 and in 2015-16 again it decreased to $656 \mathrm{~kg} / \mathrm{ha}$.

Land application designs, somatic topographies of the land, the country cultural unity and the colonial regime before independence were the factors that affected agriculture in India. The state of Punjab was made up of sandbar, alluvial plains, and an arid dry western region. The sandbar covered 
about 20 per cent of the total area of the state and it occupied by 20 per cent of its population (Bhalla, 1995). Punjab was the last state which was occupied by British in 1849, and at that time the only sources of water for irrigation and human consumption were rainfall and wells. Production in Punjab agriculture started while the British made huge investments in irrigation canals in the state in the late nineteenth and early twentieth centuries. Capital cost on useful irrigation channels in Punjab was forty per cent of the total made by the British government in India up to 1919-20. Thus, the segment of irrigated lands in Punjab was 50 per cent of the total for agriculture acreage (Hirashima, 1978). Punjab Agri-Horticulture society was created in 1851 by the British which was an important development in the agriculture policy. During the 20 years period from 1851 to 1871 , the society tried to improve the agriculture products of Punjab (Kerr, 1976). Punjab Agriculture College was established at Lyallpur in 1909. Other agriculture canters were stated at Gurdaspur in 1909 and at Jullundur in 1912-13 to exhibit the techniques of dry farming to the farmers (Bhalla, 1995). The production of cereals and saleable crops increased with the creation of channels during the first half of the twentieth century. The yield of wheat, maize, sugarcane, and cotton increased from 0.87 million tonnes, 0.28 million tonnes, 124,000 tons, 70,000 bales in 1904-05 to 1.17 million tonnes, 0.03 million tonnes, 279,000 tons, 296,000 bales in 194445 respectively (Ministry of Agriculture, 1976).

Figure.1 Area under major crops in India (1950-2016)

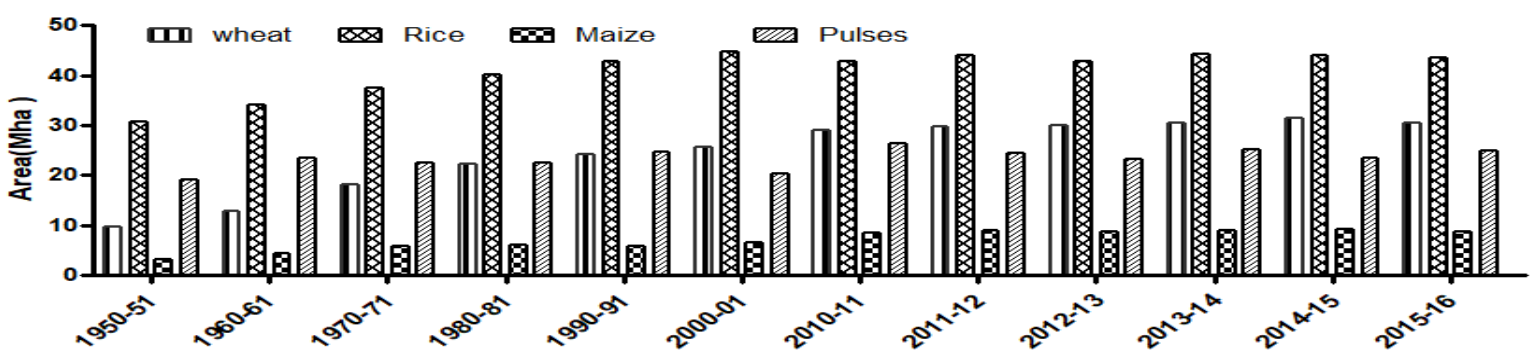

Source: Government of India, 2017

Figure.2 Production of major crops in India (1950-2016)

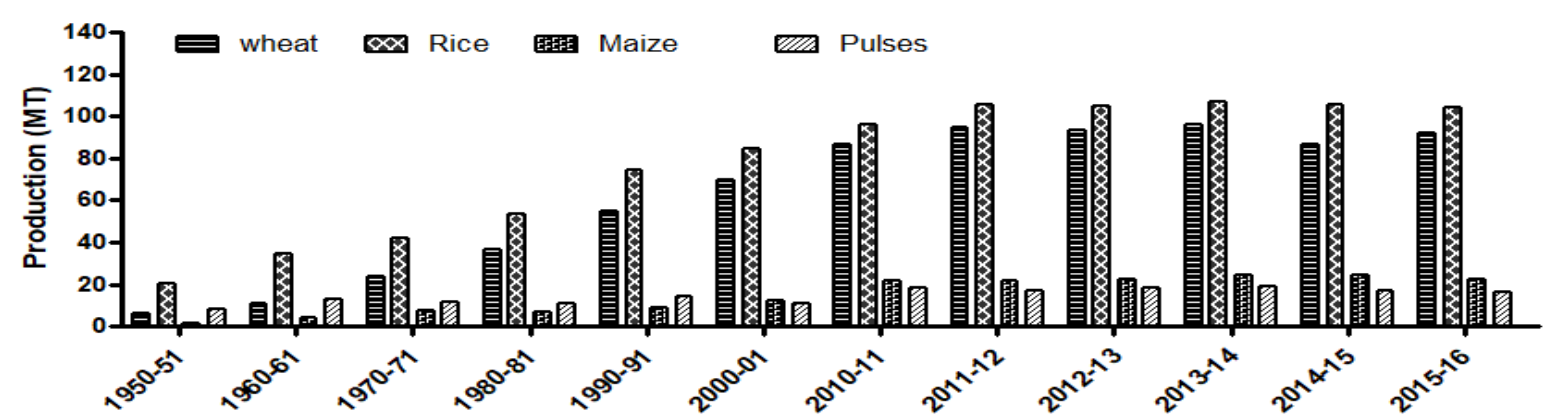

Source: Government of India, 2017 
Figure.3 Yield of major crops in India (1950-2016)

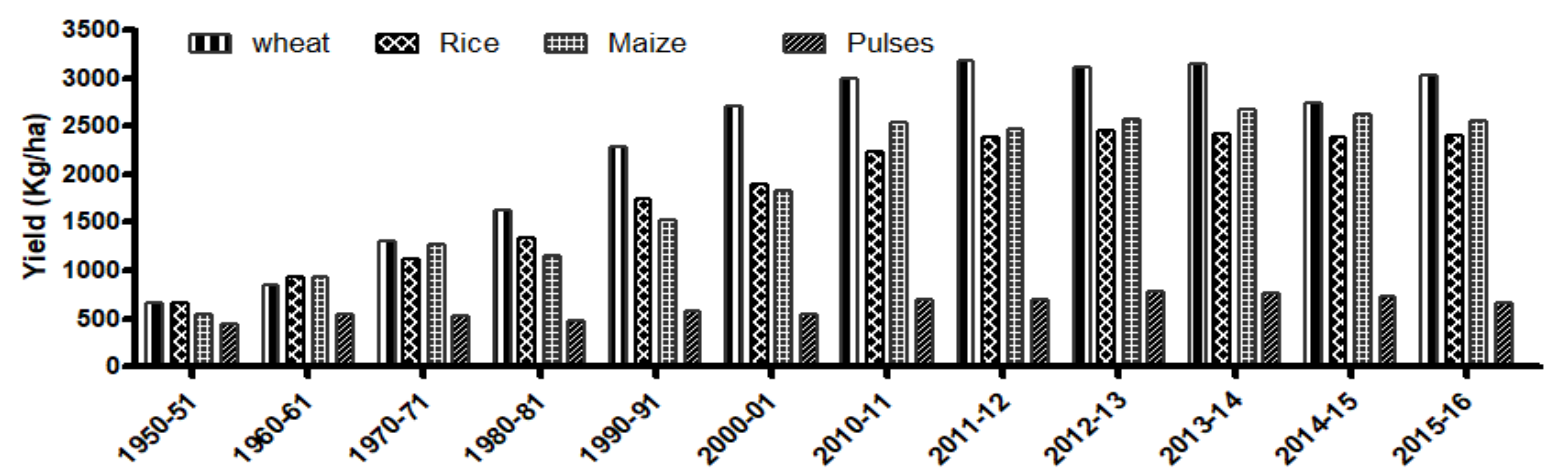

Source: Government of India, 2017

Figure.4 Area under major crops in Punjab (1950-2017)

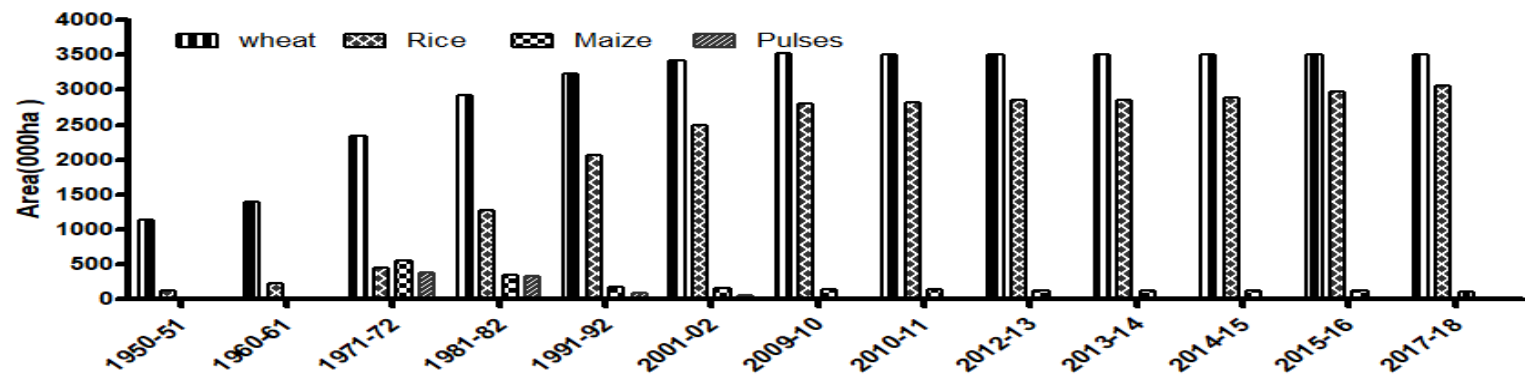

Source: Government of Punjab (Punjab at a Glance)-2018, Source 2: State agriculture ProfilePunjab, 2012

Figure.5 Production of major crops in Punjab (1950-2017)

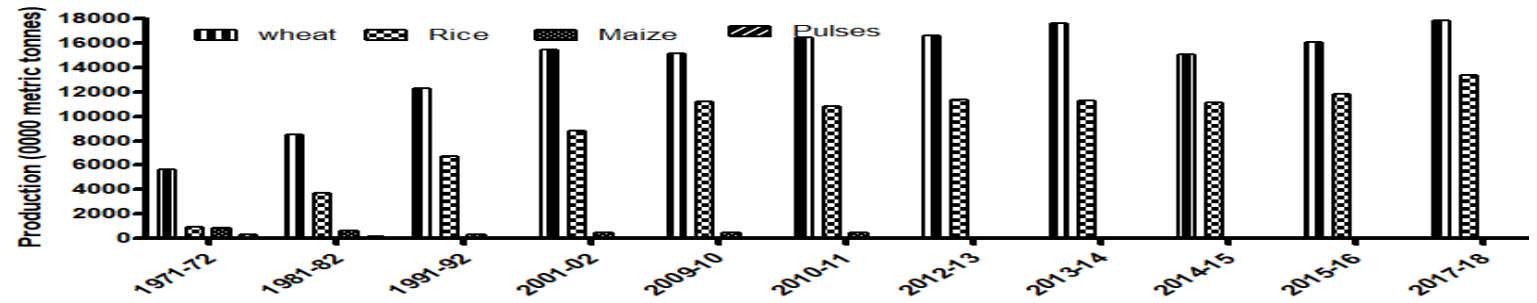

Source: Government of Punjab (Punjab at a Glance), 2018, Source 2: State agriculture ProfilePunjab, 2019

Figure.6 Yield of major crops in Punjab (1950-2017)

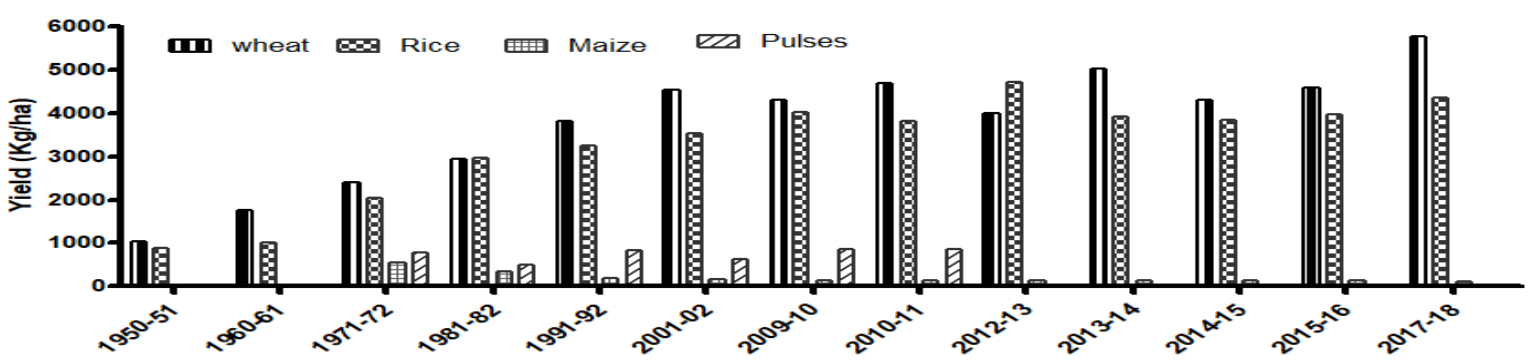

Source: Government of Punjab (Punjab at a Glance), 2018, Source 2: State agriculture Profile- Punjab, 2019 
The partition of the India and Punjab in 1947 resulted in a big setback to the Punjab agriculture, as a large part of productive and irrigated lands went to West Punjab in Pakistan and also led to the pull-up and migration of a good-sized part of the population across the border (Singh, 2001). Since the beginning of planning in 1950-51, Punjab recorded a very high rate of agricultural growth. Through the various land reforms and public investments during 1950s basic institutional and economic infrastructures were created in Punjab (Bahlla et al., 1990). The agricultural and economic growth in Punjab was associated with the Green revolution. The increase in wheat production of Punjab from 1.9 in 1965 to 5.6 in 1972 and equally strong rice production corroborates the previous statement as reported by Singh and Kohli, (2005). After adoption of new agriculture technology made up of hybrid seeds, chemical fertilizer, insect repellent, and new agriculture practices in mid-1960 Punjab made wonderful progress and in a few years, the state established itself as a heartland of India's successful green revolution policy (Sidhu, 2005). The annual rate of increase in production of food grains during the period 1961-62 to $1985-86$ for the state was more than double then that of the country as a whole. In 1974 the percentage of high yielding varieties of seed in the total area under food grains in Punjab was as high as 73 per cent while all India it was 31 per cent, which reached to 95 per cent in 1983-85, while it was 54 per cent in all India (Jodhka, 2006).

Area, production, and yield of major crops in Punjab are shown in figure 4,5 , and 6 respectively. The area under wheat and rice in $1950-51$ was $1,137,000$ ha and 120,000 ha which increased to $3,512,000$ ha and $3,065,000$ ha in $2017-18$ respectively. The yield of wheat increased from $1,024 \mathrm{~kg} / \mathrm{ha}$ in $1950-51$ to $5,777 \mathrm{~kg} / \mathrm{ha}$ in $2017-18$ and the yield of rice increased from $892 \mathrm{~kg} / \mathrm{ha}$ to
4,366 kg/ha in the same period. In 1971-72 the production of wheat was 5,618,000 tons which increased to $17,830,000$ tons in 2017 18. Furthermore, the production of rice in Punjab during 1970-71 was 920,000 tons while it was 13,382,000 tons in 2017-18. The area under maize cultivation in Punjab in 1970-71 was 580,000 ha which decreased to 114,000 ha in 2017-18, the yield of maize increased from $1,564 \mathrm{~kg} / \mathrm{ha}$ in $1970-71$ to $3,706 \mathrm{~kg} / \mathrm{ha}$ in 2017-18. Pulses covered 384,000 ha in 1971-72 which decreased to 20,000 ha in 2010-11. The production of pulses in 1970-71 was 302,000 tons in 197071 which decreased to 17,000 tons in 2010-11 and 9,000 tons in 2017-18 respectively.

\section{State of agriculture in India before 1947}

The history of modern agriculture in India begins in 1757. In that historic year the Indians lost the war of Plessey to the East India Company of the British soldier-traders. As a result of the failure, the income rights of a district in Bengal, the 24-Paragannahs, had to be conceded to the company. The position was occupied by British in the civil and revenue admiration of India expanded quickly. By, 1765, large lands of India, especially in the provinces of Bengal, Bihar and Orissa was under the control of the company and agriculture in India had become subjected to the British administration and its modernising influences (Bajaj et al., 2001).

Wheat, barley and jujube were domesticated in the Indian subcontinent by 9000 BC. After that sheep, goat and elephant were domesticated, barley and wheat cultivation along with the domestication of cattle, primarily sheep and goat was visible in Mehrgarh by $8000-6000$ BC. By the $5^{\text {th }}$ millennium BC agricultural societies became general in Kashmir (Zaheer, 1996). Moreover, the primary sing of cultivation of cotton had already developed and it was cultivated by the $4^{\text {th }}$ and $5^{\text {th }}$ millennium BC. The Indus cotton 
industry was well developed and some approaches used in cotton rotating and production continued to be practiced till the recent Industrialization of India. Among the fruits mango and muskmelon are native to the Indian subcontinent and hemp also domesticated by Indians which they used for a number of applications such as making narcotics, fibre and oil. Peas, sesame and dates were grown by Indus Valley farmers. Sugarcane was basically from tropical South Asia and Southeast Asia. Different species possibly invented in different locations with Saccharum barberi originating in India and Saccharumedule and Saccharum officinarum coming from New Guinea. Wild Oryza rice appeared in the Belan and Ganges valley regions of northern India as early as $4530 \mathrm{BC}$ and 5440 BC respectively. Agricultural movement throughout the second millennium $\mathrm{BC}$ included rice cultivation in the Kashmir and Harrappan regions. Mixed farming was the basis of the Indus valley economy (Murphy, 2007).

In 1857 few Indian commercial crops such as cotton, indigo, opium, and rice prepared to the global market under the Birtish Raj in India due to the construction of Rampur canal on Sutlej River as reported by Roy, (2006). The second half of the $19^{\text {th }}$ century witnessed some increase in the cultivated land at a normal rate of approximately one per cent per year by the later $19^{\text {th }}$ century. Punjab, Narmada valley, and Andhra Pradesh became centres of agricultural improvements due to wide irrigation by canal networks. The world war also influenced Indian agriculture system

From 1891 to 1946 the annual growth rate of all crop production was 0.4 per cent and food grain production was almost stagnant. There were important local and intercrop changes; however, non-food crops response was better than food crops. Among food crops the most significant source of stagnation was rice.
Bengal had under average production rates in both food and non-food crop production, while Punjab and Madras were the smallest stagnant states. Population growth accelerated in the interwar period where food production slowed, most important declined the availability of food per head. The crisis was most serious in Bengal, where food production dropped at a yearly rate of nearby 0.7 per cent from 1921 to 1946, when population grew at a yearly rate of about 1 per cent (Roy, 2006).

Agriculture performance in the interwar period was depressing. Cotton, indigo, opium and rice were the profitable crops which reached the worldwide market under the British Raj in India. The yearly growth rate of all crop production was 0.4 per cent and food grain yield was stagnant from 1891-1946. There were major regional and intercrop differences, and non-food crops were doing well than food crops (Brothwell, 1975).

In the context of economic liberalisation during 1900s (Kurosaki, 1999), investigated the performance of agriculture in India and Pakistan, from historical and comparative perspectives. Based on a new data set that corresponds to the current border, the stagnant performance of agriculture in India and Pakistan throughout the foreign period was turned into a sustained development since 1947, with a stronger performance in India particularly in terms of each capita food invention. The author mentioned that the changes had significant effect on agriculture production in India and Pakistan. Farmers had responded to changes in establishments and strategies, regulating their crop mix and production technology.

Many significant improvement were seen in the agricultural statistics of India after the First World War (Nath, 2008). The Royal Commission of Agriculture was appointed in 1926 by Government of India to observe the 
situations of agricultural and rural economy and the reports were published in 1928. The Commission suggested the constitution of the Imperial Council of Agricultural Research which was renamed after independence as the Indian Council of Agricultural Research.

The economic history and the degree of development of Indian agriculture from 1891 to 1947 were studied by Blyn, (1966), which closely examined the output, area and yield for eighteen crops that reputed most of agriculture in India. Author combined the output and trade data to determined trends in the availability of crops. Also, these trends were compared with population statistic to designate changes in India's prosperity. Close examination was given to variations of output, intensity of cultivation, agriculture technology and physical environment.

\section{State of agriculture in India from 1947- 1970}

Institutional and infrastructural reforms were introduced in India since independence for the development of agriculture sector. From independence to mid-sixties, Indian agriculture witnessed incredible agricultural reforms, development of important irrigation project and supports for cooperative credit organization. In mid-1960 new agricultural strategy was introduced. In this period India became self-sufficient in food grains. Agricultural transformations during this period took back seat while research, price support, marketing, input supply, credit, extension, and spread of technology were the primary concern of agricultural strategist (Rao and Hanumantha, 2000).

When independence came to India, agriculture was crossing a bad period, especially in Bengal which had recently faced a major famine. The per capita food availability in 1946 was 417 g daily which was very low. Indebtedness in rural areas was almost doubled between 1929 and 1936. India was facing a serious shortage of food and commercial crops.

Improvement of agriculture was an urgent demand at that period. A noticeable mode of action was focused on the improvement of irrigation system which was exhausted after partition. In addition of improving irrigation some steps were taken to bring the farmers back on the land and decrease rural indebtedness through land reform. The average irrigated agriculture land area increased to 20.2 million hectares from 18.9 only in three years between 1947 and1950 (Bajaj et al., 2001).

At the time of independence in India agriculture was the major source of income and occupation (Tripathi and Parsad, 2010). Agriculture and associated activities funded about fifty per cent to India's gross income, approximately 72 per cent working population was engaged in agriculture, which confirmed the backward economy of India and agriculture based economy at the time of independence. After 1947 India made much progress in agriculture and India's agriculture increased at the rate of 2.6 per cent per year. After that the focus of increased land area under agriculture production decreased over the time and productivity became the primary source of growth in agriculture production. Another vital side of agriculture development in India was the eradication of its requirement on imported food grains. All mentioned developments in India's agriculture were contributed by series of steps such as land reform, inauguration of agriculture, new agriculture strategy investment in research and etc., introduced by Government of India.

Food grins production in Indi increased from 55.0 million tonnes to 108.4 million between the years of 1951 to 1971 , in an annual rate of 2.7 per cent which was slightly ahead from population growth. The development was still 
not smooth and there were fairly a few years especially 1966, 1967, and 1973 when the country experienced a severe food crisis. Throughout the period with the exception of the year of 1972 food grains had to be imported the maximum being 10 million tonnes in 1966 (Dantwala, 1976). India terms of trade improved slightly between 1950 and 1967 and the index of export and import price rose by 73 and 67 per cent respectively. After 1967 India belonged to the large group of developing countries that had included import substitution as an important element of their strategy of economic development (Cohen, 1969).

The two successive severe droughts in 196566 and 1966-67 increased the international anxieties about India's ability to feed her large and rapidly growing population (Paddock et al., 1968). During this period, the high yielding varieties of cereals became commercially accessible. India's policy maker went for it with alacrity. Dr. Norman E. Borlaug complimented the then Minister of Agriculture who recognized the significance of the new wheat strains and took the risk involved in importing 18,000 tonnes of dwarf wheat Mexican varieties.

The yield of food grains had doubled in India after the introduction of dwarf wheat seeds (Chakravarti, 1973). The high yielding variety seed program had contributed to serious interregional differences in agriculture. The surprising success of the dwarf Mexican wheat was the back bone of the green revolution. The trend had just started and affected only a small section of millions of farmers. India experienced more normal weather conditions and most high yielding varieties during 1967-68.

Dwarf wheat seeds were introduced to India in 1966-1967 and their commercial adoption had been rapid and successful (Cummings,
1970). During 1966-1967 crop years only 4.66 million were seeded under the High Yielding Varity Program (HVP) and 2.2 per cent of the total areas were under paddy, wheat, maize, and bajra but in 1968-1969 the areas under HVP increased to 22.97 million acres while the target under the fourth plan was sixty million acres. For this purpose the government established the National Seeds Corporation to provide quality seeds, financing and guidance.

Farmers in India were conservative; most of them were ready to adopt the new methods under High Yielding Variety Program (HVP). The adoption of the HVP was facilitated by the Intensive Agricultural District Program (IADP), which was built into the existing community development organization. The major objective of this program was to increase the food grain production by indicating and encouraging the adoption of improved farm practices and by making available the needed services, seeds, fertilizers, pesticides and tools. Each farmer had been helped to improve a crop production plan for his land and the success of the new high yielding seeds in IADP districts had spurred rapid diffusion (Chakravarti, 1973).

After the partition of India and Pakistan in 1947, different challenges came to India. Even during good harvest years food imports remained high. A large group of people were poor (Rena, 2013). To mitigate these problems in the mid of 1960s India adopted new farming policy under the green revolution. The green revolution had contributed to the Indian agriculture extremely and transformed India from a hungry nation to a food exporter.

Oommen (1971) studied green revolution and agrarian conflict in India, and noticed that the factors such as understand the common differences in rural poor, a practical numerical asset of the agricultural labour force and their 
awareness of their political negotiating rule, a proper support structure provided by political parties, the growing aspiration of the rural masse, and the increasing lack of fit between the socio-political framework and the economic order were involved in agrarian conflict in India. In no time and in no part of the India was rural unrest general except when the rural have-nots were mobilized by a political party or movement. Usually, the economically poor's in rural India were also under privileged and politically helpless, and their aspirations therefore remained frozen.

Owing to green revolution the impacat of intensive farming practices in India was favorable (Chuadary, 2017). Intensive farming owing green revolution initiated in Punjab, Haryana, Rajasthan and other states of India which later sepread to West Bengal. India became self-sufficient in food front as use of high yield variety seeds, irrigation water, synthetic fertilizers, agriculture machineries, pesticides and agricultural awareness of the rural brought a notable change in agriculture. This extraordinary change in farming was officially known as Green Revolution.

\section{State of agriculture in India from 1970- 2019}

The adequate experience with the new agriculture strategy allowed to ask how green the Green Revolution was and whether it was a revolution or only a small palace revolt (Abel, 1970). The author examined the demand and sully situation for agriculture products in 1970. Accordingly specified that India would easily end or become infected as an importer of 10 million tonnes of cereal grains by 1980, if this level of imports were not achieved in the severe absence, the consequences of price increases would increase sharply. The green revolution had changed the face of agriculture in India and
India became independent in its food production (Shetty et al., 2014). Because of these advanced ideas and policies the crop production in India raised to 108.46 million tons in 1970-71, to 129.6 million tons in 1982-81.

The area under wheat and rice cultivation were 23.02 per cent and 10.4 per cent in 1970-71 which increased to 23.18 per cent and 12.98 per cent in $1980-81 ; 23.0$ per cent and 13.4 per cent in 1990-91 while the land under fibre decreased from 5.14 per cent in the year of 1970-71 to 5.08 in the year of $1980-81$ and 0.22 in the year of 1990-91. Tobacco productions decreased in India after initiation of green revolution, which came down from 0.27 per cent in $1970-71$ to 0.222 in 1990-91. Accordingly, it was understandable that commercial crop took the lead in term of area (Kannan et al., 2011).

Reforms of agriculture in India were discussed by (Kannan et al., 2011). The author reported that the cropping trend in India changed over time and shifted from the growing of food grain to cash crops. The elevation in crop yield since late 1960s was a key factor for accelerated crop production in India. The usage of new crop varieties, irrigation facilities and synthetic fertilisers were important factors that ensure greater growth in crop produce. However, technical and recognized help for some crops such as rice and wheat brought major modifications in crop area and production arrangement in some region. Furthermore, crop production growth indicated that the improved income, good irrigation services, good rainfall and better fertilizers helped to progress crop output in India.

The implementation of high yielding seeds especially improved variety of wheat and the increased use of chemical made wheat production to increase by nearly 150 per cent between the year of 1965-66 to1975-76 and 
India became independent in crop production by late 1970. Enhanced agricultural yield improved the income of India which eventually led to the decline of food prices thus affecting the poverty in India World Bank (2004).

The decline in the share of agricultural workers among all workers was slower as compared to the decrease in the share of agriculture in GDP noticed as major contradictions of the Indian economy (Dev, 2009). the total agriculture workers declined slightly from 75.9 per cent in 1961 to 59.6 per cent in 1999 and 56.7 in 2004-05. As compared to the 34 per cent decline in the share of agriculture in GDP, the decline in the share of agricultural employment was only 19 per cent. This ultimately led to the slight increase in the labour productivity in agriculture and rapid increase in nonagricultural workers. In 2004-05, there were about 259 million workers among which $42 \%$ were females.

Joshi et al., (2006) reported during 1980 the national level technologies was the main reason for the increase in the crop income while upturn in costs and diversification proved to be the leading source of growth in agriculture throughout 1990. The shift to higher value crops like vegetables and fruits accounted 25 per cent and 31 per cent of crop income growth in the 1980s and 1990s respectively. Price increase was the one of the major source of growth in the northern and eastern regions throughout 1990s while in the western and southern regions crop revenue increase was run by diversification in to the higher value crops.

The form of diversification across India had been systematised and various causes of diversification had been deciphered (Singh $e t$ al., 2006). The increase in diversification index signified towards non-food grain crops in Karnataka. The index had increased and the similar increase in area under food grain indicates changed from course to fine cereals. In the year of 2001-02, major portion of export earnings came from non-traditional substances, specifically rice, fruits, vegetables, and livestock, which showed improvement to diversification. Indian agriculture had watched diversification with remarkable enhancements in the stocks of livestock and fishery sectors in the over-all income from agriculture. Inside the crop area diversification had mostly been in support of non-food grains crop in most of states in India.

In rural areas the prices of cereals were about 11 per cent lower than the urban areas in 1972-73 which increased to 16 per cent in 1993-94 (Raoand Hanumantha, 2000). In India food grains demand was declined and some of this drop specified an increase in consumer welfare. The decline was sharper in the rural areas where growths in organization made other food items and non-food commodities available. However, cereal consumption was increased among the poorest 30 per cent of the population of India.

Indian agriculture sector performed under various restrictions in the last five decades. The standard performance during late sixties, mid-seventies and early eighties helped to overcome the problem of total food anxiety (Deshpande et al., 2002). It was claimed that the annual growth of agriculture showed declined trend in the post improvement period. While it rose at a yearly rate of 3.4 per cent during 1980s, it registered only 1.8 per cent growth among 1997-98 and 200-02. Growth rate was 4.7 per cent among 1992-93 and 1997-98. Also, it was claimed that there was a decrease in area, production and productivity of all crops. Whereas, area under all crops showed a low increase in growth rate during 1990, production and yield showed a decrease trend. Nineties had positive growth 
rate in GDP in most of the years except few years, but while comparing the aggregate growth, analysts tend to conclude with a bad performance during nineties. Probably the top achieved at the end point in the period of eighties leads to such an inference. It was pretty clear that the act during eighties of the agriculture sector was quite helpful.

The agriculture growth rate recorded noticeable decreased in the post improvement period 1990-91 to 2003-04 as compared to the period of 1980-81 to 1990-91 (Rao, 2008). This declined and unproductivity of agricultural development was impact the income and job engagement of most of local people dependent on agriculture. Almost all the regions in India experienced decreasing agriculture growth. Dry land region and small and marginal farmers with limited resources were the most adverse effected.

Agriculture sector in India had a conventional long period record of enchanting the India out of serious food shortages in spite of swift population increase. This was achieved through a helpful interface of organisation, expertise, addition, and strategy support assisted by strong political resolve. Industrial expansion of production per unit of cropped area was the key source of long runs growth. This caused in boosting of food grain yields, and food grain production enlarged from 51 million tonnes in $1950-51$ to 217 million tonnes in 2006-07. Production of cotton, oilseeds and sugarcane in were also increased to 23 million bales, 24 million tonnes and 355 million tons respectively (Government of India, 2009). The area under irrigation increased by more than four million hectares from 2004-2005 until 2006-2007 which increased irrigated sown area from 40 per cent in 2003-04 to 43 per cent in 2006-07 reported by (Kapur, 2018). Green revolution has allowed the economy to stand on its own feet in the case of food grains and transformed
India from begging bowl to grain bowl (Thomas, 2018). Food cereals production increased from 52 MT in 1951-52 to 264.77 MT in 2013-14. India in 2013 raised second place in wheat and rice production and first in millet production. Accordingly, India became self-sufficient in seed production, yield improving by thirty per cent, providing of better remunerative price than before to farmers. Short maturity period of the high yielding variety seeds, as a major achievement of first green revolution and concentration of green revolution in the certain rich state like Punjab, inequalities among the farmers was an unwelcomed result of green revolution. Author suggested that India need a second green revolution by reporting the statement that India was one of the firmest growing economies in the world, and agriculture sector plays a major role in its journey headed for development by providing livelihood to the half of its work potency. But the share of primary sector in the GDP is much lower than its counterparts, which mean the expansion scheme including the green revolution tracked by the economy has failed to bring the agriculture into the main stream and we have to ensure sustainable development also.

Economic Survey showed that production per hectare of major crops such as paddy, pluses and wheat were low 2015-16 reported by Mugunthan, (2016). India's average wheat production in 2013 was $3075 \mathrm{~kg} / \mathrm{ha}$ which was lower than the world $3257 \mathrm{~kg} / \mathrm{ha}$. All India state had paddy production below that of China even most of that had yields below that of Bangladesh. India's best state, Punjab's paddy production was near to 6000 $\mathrm{kg} / \mathrm{ha}$ while China produced $6709 \mathrm{~kg} / \mathrm{ha}$.

Soil Health Card scheme is under application in India since 2015 to provide soil health care to all farmers in India. Through this scheme farmers would receive information on soil 
nutrient status of their soils and endorsement on right amount of nutrient application for improvement of soil fertility and soil chemical characteristics (Ministry of Agriculture, 2019).

\section{State of agriculture in Punjab before 1947}

British occupied Punjab in 1849, which was the last state occupied by them, at the time; rainfall and underground water through wells was the only source of irrigation. British made massive investments in the late nineteenth and early twentieth centuries in irrigation canals which caused the beginning of the agricultural production in Punjab. Capital cost on useful irrigation channels in the state was forty per cent of the total investments made by the British rule during the period of 1919-20 in India. Thus, the segment of irrigated lands in the state was fifty per cent of the total investment for agriculture area (Hirashima, 1978).

After the takeover of Punjab by the British, they paid superior attention in the direction of the process of familiarizing technological improvements in the agriculture sector of Punjab. Punjab Agri-Horticulture society was created in 1851 by the British which was an important development in the agriculture policy. During the 20 years period from 1851 to 1871 , the society tried to advance the agriculture sector in the state. So far, it was unable to attain its goals but it provided course for strategies to be assumed for the growth of agriculture in Punjab on modern lines (Kerr, 1976).

Land application designs, somatic topographies of the land, the country cultural unity and to the colonial regime before independence were the factors that affected agriculture in India. The state of Punjab was made up of sandbars, alluvial plains, and an arid dry western region. The sandbars covered about one-fifth of the total area of the state and it occupied by twenty per cent of its population. Mean rainfall was $87.20 \mathrm{~cm}$ as tube wells were tough to make in hilly regions. Only sixty per cent of the cultivated areas were watered in this part in comparison to more than 90 per cent for entire state area. The central plains which covered more than half of the total area and inhabited more than 50 per cent of the entire state population was made of old and new alluvium. Above ninety per cent of the net refined areas were watered from three recurrent rivers, many canals and large number of underground wells. The mean rainfall for this part was $57.40 \mathrm{~cm}$. This region of the state was more developed in agriculture in comparison to the other regions while the south-western part of the state was mostly sandy. Agriculture in this part was more developed than in other parts of the state and the south-western region of Punjab was sandy. Though, there were few floodplains (bet) along the river yet. Underground water was in poor condition for irrigation in most parts. More than 85 per cent of the region was watered typically from channels (Bhalla, 1995).

In 1909 the Punjab Agriculture College was established at Lyallpur with the purpose of ratifying agriculture studies, which offered a degree of B.Sc. in agriculture. Continuously other agriculture institutes were established at Gurdaspur in 1909 while another agricultural centre was established in Jullundur to exhibit the techniques of farming to farmers (Bhalla, 1995).

Furthermore, modern methods of cultivation such as better crop rotation, application of organic fertilizers and prevention of crop disease were initiated. Various research works were performed in experimental form at Lyallpur. The nitrogen assimilating crops were included in the rotation and the use of green manure was encouraged. Similarly, various rotations of 
crops were developed for the different types of land with the advances in irrigation.

The advance implement of promoting agricultural mission was enhanced through the Village Farmers Associations which was established in 1911-12. The farmers made the associations and assumed to follow the strategies of the agriculture centres in all substances linked with the agricultural enhancements. In the year 1920-21 these links were effective virtually in all districts of Punjab (Annual Reports of Punjab, 1921).

Siddiqi (1984) studied the agricultural advancements in Punjab during the period of 1850-1900. In this era the agriculture production did not change despite the advances in irrigation. The British government was believed to the idea that every individual had the right to the unlimited possession of the land. If by land policy was doomed a comprehensive, will be planned for efficient, long term use of regional agriculture resources. It was reasonably argued that the colonial administration had none. A little concentration was given by the local government to control the use of arable lands which prevented overexpansion of survived agriculture.

Since, the construction of the channels in the first half of the $20^{\text {th }}$ century, the yield of cereals and saleable crops increased. The yield of wheat, maize, sugarcane, and cotton increased from 0.87 million tonnes, 0.28 million tonnes, 124,000 tons, 70,000 bales in 1904-05 to 1.17 million tonnes, 0.03 million tonnes, 279,000 tons, 296,000 bales in 194445 respectively (Ministry of Agriculture, 1976).

Agricultural development in Punjab played an exceedingly significant portion in the situation of agricultural expansion in India. The rate of food grains production in Punjab along with Bombay made the decrease in rest of the country, the rate of increase of food grains yield at the national level was almost zero from 1891 to 1946 . The growth rate of agriculture yield for all crops in Punjab was 1.570 per cent per annum; that of acreage to be 0.960 per cent per annum and of output per acre to be 0.620 per cent per annum (Blyn, 1961). During the British period agriculture was the major source of livelihood for the most of the population and the government revenue in Punjab (Mandakini and Bath, 2016). Thus, it became one of the thrust areas that determined the British polices.

It also attributed to the transformation of the economy in the state. Accordingly, during the start of British government in Punjab, the agricultural processes in use, the feature of seeds, animal farming, crop rotation process and promotion of agriculture output was virtually becoming stagnant and useless. The British rule in Punjab opened the way for the introduction of western science and technology in the province. Numerous technological development like better irrigation structure, better livestock, the new technique of crop growing and use of more compost initiated by the British. Modification in the method of production conveyed substantial change in socio-economic format in Punjab and their effects were progressive and long-term.

In the half of the nineteenth era, the fast political change and constant warfare were adverse for the rapid expansion of agriculture science and technology. In the state, the Lahore Darbar and the East India Company were busy in the postponement of their own kingdoms. As a result more pressure was given on the development of the traditional modes of cultivation and irrigation and moderately slight was done for the introduction of new technical innovations (Singh, 1982). 
State of agriculture in Punjab from 19471970

The division of the India and partitioning of Punjab in 1947 allocated a big setback to the Punjab agriculture, as a large part of productive and irrigated lands went to west Punjab in Pakistan and also led to the pull up and migration of a good-sized part of the population across the border (Singh, 2001). This apart on the positive side, the rich experience of the migrant farmers from previous canal groups helped the conversion of fairly regressive agriculture in the Punjab. The programmers of land reforms and consolidation of holdings further supported the farmer proprietorship in land. Agricultural education and research got boost, with Punjab Agricultural University being established at Ludhiana in 1962. Administration also invested deeply in the formation of infrastructure such as construction and development of canal irrigation scheme, rural electrification, rural roads system and agriculture market, development of health and public organization and expansion of many institutions to additional agricultural development.

Since the beginning of planning in 1950-51, Punjab recorded a very high rate of agricultural growth. Through the various land reforms and public investments during 1950s basic institutional and economic infrastructures were created in Punjab (Bahlla et al., 1990). British invested in the field of irrigation, power, and research in agriculture along with market development led to the advances in agriculture in the state. Concurrently, regulations to reform lands were passed and brought into effect. Accordingly these land reforms were unsuccessful to bring any improvement in land ownership, but the policies were successful in removing the intermediaries and decreasing the occupancy. These reforms during at the beginning of independence years placed the foundations for swift growth and transformation of agriculture. The state of Punjab recorded high agricultural growth due to the huge investment in irrigation, rural organisation and improvement of institutional structure during the period of 1950-51 to 1964-65.

Technological changes expanded production by raising the efficiency of input used and elevated engagement by increasing the demand for labour. But the comparative growth proportions of output and employment were depended upon the kind of technical change. There was a close association between the level of technology, agricultural expansion and the design and amount of labour employment. In the Punjab state, agriculture has experienced a quick technological transformation in the system of seed, irrigation method, and fertilizer with the advent of Green revolution (Sidhu and Grewal, 1990).

Agriculture development in Punjab was highly related with the well-recognized of Green Revolution which led to the development and use of modern high yielding varieties of food crops especially wheat and rice. The inspiring agriculture improvement in Punjab was showed by the elevation in the conditions of wheat production that increased to 5.6 million tons in 1972 from 1.9 million tons during the year 1965. Similarly Singh and Kohli (2005) reported massive growth in rice production.

After adoption of new agriculture technology made up of hybrid seeds, synthetic fertilizer, insect repellents, and new agriculture practices in mid-1960 the state made wonderful development and in just few years, the state established itself as a hub of India's successful green revolution policy (Sidhu, 
2005). These modern technologies focused to achieve changes in the agriculture system. After initiation of modern technologies in 1966, Punjab witnessed huge development in agriculture system. The author mentioned that it was essential to recognize that the Punjab agricultural system would not be same as what it is today, if India did not pick in favour of new system of agriculture to resolve the lasting food scarcity which it suffered in late 1950 and early 1960 .

Singh (2011) reported that the conformity of different new agriculture methods had supported the role of agricultural sector in the economy progress and employment generation of Punjab. The cropping concentration in Punjab was the highest among the Indian states. The invention and output of main crops increased few times due to the beginning of green revolution, but it limited the state to produce only two crops such as wheat and paddy, which resulted in unhealthy soil, pest infected crops, damaged groundwater and water logging wages.

The Green Revolution brought a swift development in agriculture of developing countries because of modern mechanical and petrochemical efforts throughout 1960s and 1970s, which was the beginning of modern wealth intensive agriculture in India (Dutta, 2012). Punjab was chosen as the first state for the initiation of Green revolution in India, although it was relatively dry, there had been extensive development of irrigation system during the British rule. Additionally, Punjab was also home to large number of wealthy farmers who became the earliest receiver of the benefits of green revolution (Sebby, 2010).

Interdiction of seed and fertilizer technology in Punjab during the mid-1960 brought huge change which led to extraordinary growth of agriculture output, particularly for wheat and rice (Bhalla et al., 1990). Due to close input, feeding linkage and yield swift agricultural improvement was achieved by even faster growth in the industrial sectors. Thus, total income of the state increased to 5.0 per cent during 1960-61.

Punjab experienced a remarkable agricultural growth which was the highest among all the other states during the period of 1960s to the mid-1980 (Datta, 2012). It helped to improve the social and economic condition of the farmers and hurled it to the status of being called the "grain bowl of India". After that agriculture production sector in Punjab became extremely capital intensive and mechanised. During the period of 1960s to mi-1980 the state reached 95 per cent irrigation coverage of net agricultural area and 98 per cent gain in high yielding seed varieties.

Use of agricultural machinery and inorganic fertilizers greatly declined the employment rate in the state, while technological parameters such as cultivated area, cropping intensity, higher use of inputs, etc. increased labour use (Singh and Singh, 2006). The back-and-forth of these factors resulted in net decline in the human labour requirements. The author pointed out that the total requirements of Punjab agriculture was 651 million man days which dropped to 638 million man days in 1970 to 1971.

\section{State of agriculture in Punjab from 1970- 2019}

Punjab agriculture development rate was the highest among the other states of India during the 1960s until the middle of the 1980. The rate of agricultural yield income was almost double than the income of the rest of the nation during the period of 1961-62 to 198586 . The use of high yielding varieties of crops in Punjab was 73 per cent where as it 31 per cent in India, which further was increased to 95 per cent I 1983-85, while it was 54 per cent in all India. Although Punjab had 17459 
tractors per 100,000 holding tractor while in India it was only 714 . It was not only to the new agricultural technologies and high yielding varieties of seeds that the accomplishment of the green revolution was endorsed. The hard work and innovation of the farmers of Punjab was also highly praised. Their adoration for acreage and the attachment of them to the self-cultivation were the key which made the green revolution a success story in the area much before it spread to other state of India (Jodhka, 2006)

Bhalla et al., (1990), reported that the share of area under wheat cultivation in the net agriculture area increased from 26.9 per cent in $1950-51$ to 44.1 per cent in 1984-85. The shear of rice increase to 23.4 per cent in 1985 from 5-6 per cent in 1965. For other crops, the area under cultivation decreased after the green revolution. Accordingly, yield grew remarkably in rice and wheat as compared to rest of the crops. Wheat produce grew by 2.6 per cent per annum during 1967-68 to 198485. The increase in rice yield was very impressive as it increased to 5.7 per cent in the post 1967 years from 1.7 per cent per annum in the pre green revolution era. Wheat output increased from 2.4 million tons in 1964-65 to 10.2 million tons in 1984-85. The production of rice was increased to 5.10 million tons in 1984-85 from 0.5 million tons in 1969-70. During this period rice and wheat became the major crops for cultivation in the state and it was related to the huge proportion of total agriculture yield.

In the 1970s and 80's a large number of small farms were unable to keep up with the competition. There were 1,375,382 landholdings in Punjab in 1971, and this number fell to $1,027,127$ by 1981 . This decline of nearly 25 per cent of the farms of Punjab led to a shift towards large farms. In 1984, 24 per cent of small farmers and 31 per cent of marginal farmers were living below the poverty line (Singh, 1984). From 1977-79 there was an increase in per hectare income while, the financial returns from farming were decreased in Punjab (Sebby, 2010).

There was a rapid increase in the productivity of wheat and paddy during the initial years of the green revolution in Punjab. This was because of the larger use of new efforts such as fertilizers, irrigation; high yielding varieties of seeds and greater mechanization. In spite of these high doses of these inputs, productivity growth became slower and in the case of wheat, it was nearly established (Kaur et al., 1990). The slow growth in productivity was complemented by quick growth in costs leading to a fall in the returns. The net returns over active costs from wheat cultivation per hectare at 1970-71 prices dropped from Rs 328 in 1971-72 to RS 54 in 1981-82. With the failure in the rate of return, small holdings were no longer workable. In the early 1970s, the green revolution backed to the stability of small farmers but in the late 1970s the load of economic crisis became more severe and intolerable, this headed to the breakdown of small and marginal farmers. Accordingly, between 1970-71 and 1980-81 there was a decline in the number of marginal holdings by 61.9 per cent and that of small holdings by 23.3 per cent. There was an increase in the number of medium, large and extra-large assets respectively by 2.3 per cent, 8.6 per cent and 7.3 per cent respectively. The net result was, 25.3 per cent of total operational holdings, disappeared during the 70 s.

Diversification of agriculture in Punjab started on November 8, 1985, while the government of Punjab selected an expert committee, headed by Dr. S.S. Johal. Committee made some recommendations and submitted its report in May 1986. Since the committee was selected to look into the opportunities of diversification of agriculture, its agenda was concerned mainly with agriculture. After investigative economies of 
numerous creativities and given attention to various possibilities, the committee concluded that the impact of diversification power will not be felt except at least 20 per cent of the area occupied by wheat and paddy crops were diverted to other crops (Government of Punjab, 1986)

Agricultural diversification was suggested as the future strategy to address the problems and challenges in Punjab agriculture. Chand, (1999) studied the range of agricultural diversification by examining several proportions of the recommended alternative. The author discussed the predictions of the diversification alternative and its allegation on employment, income, natural resources, and ecology. Also, a strategy for the agricultural and economic development of Punjab in the post green revolution was suggested by the author.

The period of the 1970s and the 1980s was the excellent era for the agricultural economy, when the production of important crops developed expressively, the income of farmer's improved, agricultural employment increased and the national food economy turned from being deficient to self-sufficient while the era of the 1990s was serious for the farming economy of Punjab (Sidhu et al., 2005).

The area under cotton was harmfully affected after the mid-1990s because of harsh weather and insect attack, its share in gross crop area decreased to 5.97 per cent in 2000-01, but in 2007-08 it again began to increase and became 7.69 per cent due to introduction of $\mathrm{Bt}$ varieties. The areas under cultivation of sugarcane, potato did not changed, pulses and oilseeds decreased to 0.25 and 0.71 per cent in 2010-11 from 7.29 and 5.20 per cent in 1970-71(Singh et al., 2012). The contract farming program launched by the Punjab government in October 2002, was expected at taking away 10 lakh hectares from the wheatpaddy revolution over the next five years as part of the crop adjustment program (Singh and Kohli, 2005). In 2002, a total of 29,000 acres had been sustained by the Punjab Agro Foodgrains Corporation (PAFC) under the program, applied jointly by the Department of Agriculture, Punjab Agro Industries Corporation and private companies. The PAFC not only delivered seeds purchased from there believed seed companies but also promised to purchase back the whole yield at pre-decided prices through a $3^{\text {rd }}$ party agreement.

Punjab occupies only 1.5 per cent land of the country but it contributing $40-50$ per cent rice and 60-65 per cent wheat to the central pool for the last 30 years. The agricultural land under food grains reached to $634,00 \mathrm{sq} \mathrm{km}$ from 39,200 sq $\mathrm{km}$ and the production rice and wheat reached to 0.32 from $0.18 \mathrm{~kg} / \mathrm{m}^{2}$ and $0.43 \mathrm{~kg} / \mathrm{m}^{2}$ from 0.22 respectively (Aggarwal et al., 2009). This modification in agricultural system improved the need of irrigation water and the watered land reached to 95 per cent from 71 per cent in Punjab. Thus, there was a dire need to change at least 5 to 10 per cent of land under paddy cultivation, adoption of effective water management system and underground water supplementation technology on large scale for sustainable agriculture.

Punjab was a symbol of India's grain over supplies, giving India a much-needed food security but after 1985-86, green revolution started slowing and growth in Punjab agriculture decreased to 3 per cent per annum over the period of 1985-86 to 2004-05, virtually same as achieved at all India level (Gulati et al., 2017). During 2004-05 to 201415 Punjab faced a real challenge, while its growth slowed down to just 1.6 per cent per annum, which was less than half of the all India Agri-GDP growth of 3.5 per cent over 
the same period. Providing food security to the country and reducing its own poverty to lowest levels within all India context, were the most admirable achievements of Punjab. Then, recently Punjab lost its well-known position of being the state with the highest per capita income in India, a title it carried since its beginning in 1966 till 2002-03. In 2014 Punjab stood at $7^{\text {th }}$ position in per capita income amongst 21 major states of India.

Soils of Punjab were developed on alluvium at the initial to the medium stage of profile development. They were generally very deep, porous, sandy loam in texture, and showed weak to moderately developed soil structures with good soil, air, and water relationship.

With intensive agriculture surface crusts, subsoil compaction, soil erosion, development of hardpan, development of fine-textured, sodic soils, pollution from agrochemicals, nutrient imbalance decline in quality and quantity of soil biomass and slow rate of decomposition of crop residues were the major problems being faced by the Punjab soils. In 2010-11, about 31,000 ha of land were reclaimed in Punjab through the application of 20 thousand tons of gypsum. And a total of 5.91 lakh ha of land was reclaimed through gypsum application in Punjab so far (Singh et al., 2012).

The total food grains production in Punjab increased to 290.92 lac metric tonnes in 201112, showing an increase of about four times. Wheat and rice played a major role in increasing agricultural production significantly in Punjab. The production of rice increased from 6.88 lac metric tonnes in 1970-71 to 105.42 lac metric tonnes in 201112 , which shows a very significant hike of over 15 times.

Similarly, the production of wheat has increased from 51.45 lac metric tons in 1970-
71 to 179.82 lac metric tonnes during 2011-12 registering an increase of over 3 times. During 2010-11, the total cropped area of Punjab was 7882 thousand hectares; about 92.76 per cent was under 17 major crops in all districts of the state (Punjab Government, 2019).

Sustainability of resource use in Punjab was studied by (Taneja et al., 2018). The indexes were based on three components namely land, water, and air. The data were deployed on five indicators pertaining to these components from 1970 to 2015. The overall index showed a decline in resource sustainability in the entire Punjab. Majority districts in the central and south-western regions became highly unsustainable overtime. Thus, a regular assessment of the sustainability of resourceuse was required and this index could be useful for effective policy decision making. The overall index highlights the nature of resource sustainability. It raised awareness and understanding of district-level differences in sustainability. It aimed to trigger interventions leading to sustainable solutions in agriculture for Punjab.

Punjab witnessed a total annual wage of farmers from Government Procurement of Foodgrains was increased to Rs 1.24 Lakh Crore since April 2017 which was a rise of about Rs. 30,000 Crore over the earnings in the consistent procurement seasons of the previous Government and formers profits through the selling of food grains increased by 32 per cent. Overall Production of Cereals was increased from 30.75 Million Tons in 2016-17 to 31.7 Million Tons in 2017-18. Despite heavy rains and inclement weather, the production in 2018-19 was 31.50 Million Tons. The Agriculture Produce Markets act was modified to ensure agricultural marketing reforms and greater use of technology. Punjab State Council for Agricultural Education was established in Punjab to promote agricultural 
education in 2017. Accordingly, The Gross State Domestic Product had raised about 23 per cent from Rs 4.28 lakh crore in 2017- 18 to Rs. 5.18 lakh crore in 2018-19 (Punjab Government, 2019).

Over a period of 190 years, there was hardly any change in the form of technology in India from 1757 to 1947 . For most of the farmers, agriculture was a means of existence; nearly 70 per cent of the total population derived their livelihood from agriculture itself. Since the beginning of $19^{\text {th }}$-century, agriculture did not contribute significantly in the economic growth of India. Before the initiation of the planning era in 1951, the progress of India's agriculture was quite deplorable. Then from mid-1960 onwards the traditional agriculture practices were continuously replaced by modern technology and farm practices in India. The Green Revolution started in India during the 1960s to elevated the food production and feed the millions of people across the country. It was also credited with increase in agricultural yields in many places where the technology was accepted.

Land application designs, somatic topographies of the land, the country cultural unity and the colonial regime before independence were the factors that affected agriculture in India. The state of Punjab was made up of sandbar, alluvial plains, and an arid dry western region. The sandbar covered about 20 per cent of the total area of the state and it occupied by 20 per cent of its population. Punjab was the last state which was occupied by British in 1849, and at that time the only sources of water for irrigation and human consumption were rainfall and wells. Production in Punjab agriculture started while the British made huge investments in irrigation canals in the state in the late nineteenth and early twentieth centuries. Since the beginning of planning in 1950-51, Punjab recorded a very high rate of agricultural growth. Through the various land reforms and public investments during 1950s basic institutional and economic infrastructures were created in Punjab. The agricultural and economic growth in Punjab was associated with the Green revolution.

\section{Acknowledgement}

I am extremely grateful to my advisor and Department of Soil Science and Agriculture Chemistry, LPU, Punjab for providing all facilities during my research work.

\section{References}

Abel M. E (1970) Agriculture in India in the 1970s. Economic and Political Weekly, Vol. 5, No. (13), Pp. A5-A14.

Brothwell D (1975) Early history of agriculture. Nature, 255(5507), Pp. 368-370. https://doi.org/10.1038/255368a0.

Bajaj J.K, Srinivas M.D (2001) An Indian perspective science and technology in Independent India, Green Revolution: a history perspective, Centre for policy studies

Blyn George (1966): Agricultural Trends in India, 1891-1947: Output, Availability, and Productivity, University of Pennsylvania Press, Philadelphia, Page 374, ISBN 9781512800845.

Chaudhary D (2017). The green revolution in India: Impact and the path ahead, International conference on recent development in engineering science, Humanities and management, ISBN-97886171-36-8, www.conferenceworld.in.

Cummings R.W (1970) Seed Production in India, A. H. Bunting ed, Change in Agriculture, New York: Praeger, pp. 137-45.

Chakravarti A. K (1973) Green Revolution in India, Taylor and Francis, Ltd. on Behalf of the Association of American Geographers, Vol. 63, No. (3), Pp 319-330

Cohen B. I (1969) The International development of India and Pakistan. Economic Growth Center, Yale University, Vol. June, No. (1), Pp. 1-44. 
Dantwala M (1976) Agricultural Policy In India Since Independence. Indian Journal of Agricultural Economics, Vol. 31, No. (4), Pp. 31-53.

Dev S (2009) Challenges for Revival of Indian Agriculture, In Agricultural Economics Research Review, Retrieved from http://ageconsearch.umn.edu/bitstream/573 79/2/2-Mem-Lecture.pdf

Deshpande R.S, M. Indira (2002) Globalisation and Indian Agriculture : Performance Under a New Paradigm, University of Mysore, Mysore, Pp. 28-49.

Gillespie, Stuart, and Jody Harris S. K (2012) The Agriculture-Nutrition Disconnect in India: What Do We Know?, International food policy institute, Discussion Paper 01187

Government of India (2009). Eleventh five year plan - agriculture (2007-2012). Oxford University Press, New Delhi. vollum-III Retrieved from http://www.planningcommission.nic.in

Government of India (2016) State of Agriculture 2005-16, Ministry of Agriculture and Farmers Welfare Department of Agriculture, Cooperation and Farmers Welfare Directorate of Economics and Statistics, KrishiBhawan, New Delhi110001.

Joshi P.K, Partap Singh (2006) Source of Agriculture Growth in INdia: Role of diversification towards High Vlue Crops, International Food Policy Research Institute, Vol. 2, issue (November), Pp. 124.

Kapur R (2018) Progression of Agricultural Sector in India, Acta Scientific Agriculture, Vol. 2, No. (10), Pp. 134-138. ISSN: 2581$365 X$.

KumarArchit, Nayak, and Nahar Singh (2018) Growth, Instability and Export Performance of Banana in India, An Economic Analysis, Agricultural Situation in India.

Kannan Elumalia, and Sundaram Sajata (2011) Analysis of Ternds in Indias Agricultural Growth, The Institute for Social and Economic Change, Bangalore, Pp. 1-25.

Kurosaki $T$ (1999) Agriculture in India and Pakistan, 1900-95: Productivity and Crop Mix. Economic and Political Weekly, Vol. 34, No. (52), Pp. A160-A168. Retrieved from http://www.jstor.org/stable/4408772 Mugunthan K (2016) The economic survey 201516: productivity of crops like wheat, paddy and pulses, The Economic Times, report No. 51153300

Ministry of Agriculture (2019) Year-end review 2018 ministry of agriculture, cooperation, and Farmer Welfare, 14-16 IST, Pp-24, available on https:/pib.in/newsite/pritRelease.aspx?relid $=186796$

Murphy Denis J (2007) People, Plants and Genes: The Story of Crops and Humanity, Oxford University Press, ISBN 0-19-920713-5

Nath S.K (2008) Manual on Area and Crop Production Statistics, Center Statical Organization, Retrieved from, http://mospi.nic.in/sites/default/files/publica tion_reports/manual_area_crop_production _23july08_1.pdf

Oommen T. K. (1971) Green Revolution and Agrarian Conflict. Economic and Political Weekly, Vol. 6, No. (26), Pp. A101-103.

Paddock, William and Paul (1968) Famine 1975!, Wiedenfeld and Nicolson, London.

Rao V. M (2008) Sustainability of Indian Agriculture: Towards as assessment, Institute for Social and Economic Change, Bangalore, Pp1-28.

Rena Ravinder (2013) Green Revolution: Indian Agricultural Experience, A Paradigm for Eritrea, New Jersey, USA: Eritrean Studies Review, A Biannual Journal Published by the Red Sea Press, Vol. 4, No.1, pp.103-130

Rao C.H, Hanumantha (2000) Declining Demand for Foodgrains in Rural India: Causes and Implications, Economic and Political Weekly, Vol. 22, Issue. (January): Pp. 201206.

Roy T (2006) Agricultural Prices and Production, 1757-1947", Encyclopedia of India, Vol. 1, edited by Stanley Wolpert, Pp. 20-22, Thomson Gale, ISBN 0- 684-31350-2.

Shetty P. K, Manorama K, Murugan M, and Hiremath M.B (2014) Innovations that shaped Indian agriculture-then and now. Indian Journal of Science and Technology, Vol. 7(8), Pp. 1176-1182.

Singh N. P, Kumar R, and Singh R.P (2006) Diversification of Indian Agriculture: Composition, Determinants and Trade 
Implications, Agricultural Economics Research Review, Vol. 19, Issue. July, Pp. 23-36.

Tripathi A, and Prasad A. R (2010) Agricultural Development in India since Independence: A Study on Progress, Performance, and Determinants. Journal of Emerging Knowledge on Emerging Markets, Vol. l(1). $\quad$ https://doi.org/10.7885/1946$651 \mathrm{x} .1007$

Thomas J (2018) Policy Concerns Of Second Green Revolution: A Comprehensive Analysis. Economic Development of India, Vol.1, Issue. (1), Pp. 16-24.

World Bank (2004) India: Re-energizing the Agricultural Sector to Sustain Growth and Reduce Poverty', Report No 27889-IN.

Zaheer Baber (1996) The Science of Empire: Scientific Knowledge, Civilization, and Colonial Rule in India, State University of New York Press, ISBN 0-7914-2919-9.

Aggarwal R, Kaushal M, Kaur S, and Farmaha B (2009) Water resource management for sustainable agriculture in Punjab, India, Water Science and Technology, Pp. 29052911.

https://doi.org/10.2166/wst.2009.348.

Annual Report of the Department of Agricultural Punjab for the year 1906-07, (1907)Lahore, Punjab State Archives (P.S.A.), Patiala, Pp. 35

Annual Reports on the Administration of the Punjab for the year 1920-21,(1921) Lahore, Punjab State Archives, Patiala, Pp. 65

Bhalla G. S, Chadha G.K, Kashyap S.P, and Sharma R.K (1990) Agricultural growth and structural changes in the Punjab economy: an input-output analysis. In Research Report - International Food Policy Research Institute, (Vol. 82).

Bhalla G.S (1995) Agricultural growth and industrial development in Punjab, Agriculture on the Road to Industrialization, Pp. 67-112.

Chand R (1999) In Punjab Agriculture Emerging Crisis. Economic and Political Weekly, Vol.34, Issue. (13), Pp. 2-10

Dutta S (2012) Green Revolution Revisited: The Contemporary Agrarian Situation in Punjab, India,Social Change, Vol.42, Issue.(2), PP. 229-247. available on https://doi.org/10.1177/0049085712042002 05

George Blyn (1961) Agricultural Trends in India, 1891-1947, Output, Welfare and Productivity, University of Pennsylvania, $\mathrm{Ph}$. D. Thesis

Government of Punjab (1986) Report of the Expert Committee on Diversification of Agriculture in Punjab, May, Pp 43.

Gulati A, Roy R, and Hussain S (2017) Getting Punjab Agriculture Back on High Growth Path: Sources, Drivers and Policy Lessons, Indian Council for Research on International Economic Relations Core 6A, 4th Floor, India Habitat Centre, Lodhi Road, New Delhi 110003, India

Hirashima, Shigemochi(1978) The Structure of Disparity in Developing Agriculture, Institute of Developing Economies,Tokyo, Pp. 22-35.

Kerr, I.J. (1976). The Panjab Past and Present, 1851-1871,The Agri-Horticultural Society of the Punjab Patiala,Punjabi University, Pp.252-56.

Jodhka S. S (2006) Beyond "Crises": Rethinking contemporary Punjab agriculture, Economic and Political Weekly, Vol. 41, Issue. (16), Pp. 1530-1537.

Kaur Gill K, and Singh Gill S (1990) Agricultural Development and Industrialisation in Punjab: Some Issues Related to the Pepsi Model, Economic and Political Weekly, Vol.25, Issue (45), Pp. 2507-2509.

Ministry of Agriculture(1976) Report of National Commission on Agriculture, New Delhi: Controller of Publication.

Mandakini T, and Bath K.S (2016) Modernization of Agriculture in Colonial Punjab and its impact on the Rural Economy, International Research Journal of Soil Science, Vol.5, Issue. (July), Pp. 52-55.

Punjab Government (2019) Some key achievement of the government of Punjab, As on 31/7/2019

Siddiqi A.H (1984) Nineteenth century agricultural development in Punjab: 18501900Indian Economic and Social History Review, Vol.21, No. (3), Pp. 293-312.

Singh, Sukhwant (1982) Agricultural science and technology in the Punjab in the nineteenth century, India Journal of History of 
Science, Vol. 17, Issue, 2: 191-204, Pp. 114.

Sidhu R.S, Grewal S.S (1990) Factor affecting demand for human labour in Punjab agriculture: An econometric analysis, India Journal of Agricultural Economic, Vol. 45, Issue. 2, Pp. 2-10

Singh, H (2001) Green revolutions reconsidered : the rural world of contemporary Punjab. Indian Journal of Agricultural Economics, Vol. 57, Issue.(2), Pp273-276.

Singh N, and Kohli D (2005) The green revolution in Punjab, India: the economics of technological change. Journal of Punjab Studies, Vol.12, No. (2), Pp. 285-306.

Sidhu H.S (2005) Production condition in contemporary Punjab Agriculture, Journal of Punjab Studies, Vol. 12, No. 2, Pp. 197219

Singh G, and Singh J (2006) Green revolution and economic plight of agricultural labour in
Punjab, Indian Journal of Labour Economics, Vol. 49, Issue.(4), Pp847-854.

Sebby Kathryn (2010) The Green Revolution of the 1960s and its impact on small farmers in India, Environmental Studies Undergraduate, Punjab. Journal of Economic and Social Development, Vol.2, Issue. (1), Pp. 64-74.

Singh J, Dhaliwal T, and Grover D (2012) State Agricultural Profile-Punjab, In AgroEconomic Research Centre, Department of Economics and Sociology, Punjab Agricultural University, Ludhiana.

Sing N, and Kohli D.S, (2005) The green revolution in Punjab, India: The economics of technological change, Journal of Punjab Studies, Vol. 12, No. 2, Pp. 271-285.

Taneja G, Rawat S, and Vatta K (2018) Towards unsustainable resource use in Punjab agriculture. Indian Journal of Ecology, Vol. 45, No. (2), Pp. 342-346.

\section{How to cite this article:}

Jaihoon Rafie and Raj Kumar. 2020. A Review on Scenario of Agriculture in India and Punjab 1900-2019. Int.J.Curr.Microbiol.App.Sci. 9(06): 4149-4170.

doi: https://doi.org/10.20546/ijcmas.2020.906.487 